\title{
CORRESPONDENCE
}

\section{OPERATION FOR PTERYGIUM}

\section{To the Editorial Committee of the British Journal of OPHTHALMOLOGY}

SIRS,-I was interested in T. B. Rankine's article entitled "A Simple Operation for Pterygium" (Brit. J. Ophthal. (1961), 45, 816), in which the technique of excising the pterygium and leaving a bare area is attributed to d'Ombrain (1948).

This operation I learned from Sir Henry Holland in Quetta and Shikarpur in 1940. I wrote to him the other day to find out whence he obtained the technique, and he replied as follows:

I introduced it (the operation) nearly 30 years ago. I tried all the other operations, and in all the vessels grew again and the condition was as bad or worse than ever, so I felt that the only radical method of treating it was to leave a large surface bare and allow it to heal up gradually by cicatrization.

The pterygium should be pulled off the cornea with a squint hook. The hook is slipped under the lower border about $3 \mathrm{~mm}$. from the limbus and forced through the tissues and made to appear just above the upper border. The hook is then passed from above downwards to be sure that all tissues are included. With slight counter-traction with forceps on the base of the pterygium, a squint hook is now pulled slowly towards the centre of the cornea. This will strip the pterygium from the cornea in the perfect plane and so promote rapidity of corneal healing. The pterygium is then excised with scissors about $5 \mathrm{~mm}$. from the limbus.

A few tags of conjunctiva at the upper and lower edges of the bare limbus may require trimming; no stitch should be used.

The eye should be padded for about 4 to 5 days, when the bare area of sclera will be found to be covered with soft granulation tissue and partly epithelialized and the cornea will be healed.

Local steroid therapy can be now given three times a day for a few weeks.

This technique appears to give far less reaction than any other operation and the recurrence rate is probably lower than with any other.

4, ST. JOHNS ROAD, Yours faithfully,

NEWBURY, JOHN SOMERSET.

BERKS.

January 11, 1962.

\section{BOOK REVIEWS}

Vision of the Ageing Patient. An Optometric Symposium. Edited by M. J. HIRSCH and R. E. Wick. 1961. Pp. 338, numerous figs, bibl. Hammond and Hammond, London. (52s. 6d.).

This book is designed to put ocular age on the map. The increasing longevity of Western man naturally directs attention to what he is going to do with the years which medicine has added to his life, and it is self-evident that he will put them to better use if his vision is intact. The object of the book-namely, to see what can be done with the old-is admirable; small wonder that the President of the American Association of 